\title{
Lysinibacillus parviboronicapiens sp. nov., a low- boron-containing bacterium isolated from soil
}

\author{
Correspondence \\ Toru Fujiwara \\ atorufu@mail.ecc.u-tokyo.ac.jp \\ Hiroki Miwa \\ umiwa@mail.ecc.u-tokyo.ac.jp
}

\author{
Hiroki Miwa, ${ }^{1,2}$ Iftikhar Ahmed, ${ }^{1,3}$ Akira Yokota ${ }^{4}$ and Toru Fujiwara ${ }^{1,2}$ \\ ${ }^{1}$ Biotechnology Research Center, The University of Tokyo, Yayoi 1-1-1, Bunkyo-Ku, Tokyo \\ 113-8657, Japan \\ ${ }^{2}$ SORST, JST, Chiyoda-Ku, Tokyo, Japan \\ ${ }^{3}$ National Agricultural Research Centre, Park Road, Islamabad 45500, Pakistan \\ ${ }^{4}$ Institute of Molecular and Cellular Biosciences, The University of Tokyo, Yayoi 1-1-1, Bunkyo-Ku, \\ Tokyo 113-0032, Japan
}

Boron is a micronutrient required by plants (Warington, 1923) and possibly by animals (Rowe et al., 1998; Rowe \& Eckhert, 1999) and several marine algal flagellates (Loomis \& Durst, 1992). Amongst bacteria, boron is required for the growth of heterocystous cyanobacteria (Bonilla et al., 1990) and actinomycetes of the genus Frankia (Bolaños et al., 2002). However, Bacillus boroniphilus is the only known species that cannot grow without boron (Ahmed et al., 2007a). Although boron is known to be involved in quorum sensing (Chen et al., 2002), the biological functions of boron in bacteria remain elusive. Boron also has a toxic effect on living cells above a certain threshold. Because of its toxicity, boron has long been used in the treatment of recurrent vulvovaginal candidiasis caused by some species of Candida and Saccharomyces (Swate \& Weed, 1974; Otero et al., 2002). Boron is also used as a

The GenBank/EMBL/DDBJ accession number for the 16S rRNA gene sequence of strain BAM- $582^{\top}$ is $A B 300598$.

Details of the intracellular boron content of strain BAM $-582^{\top}$ and related type strains and results of 2D TLC of polar lipids of strain BAM- $582^{\top}$ are available as supplementary material with the online version of this paper. food preservative to sterilize against micro-organisms (Nielsen, 2004). Recently, Bacillus boroniphilus, Gracilibacillus boraciitolerans, Chimaereicella boritolerans and Lysinibacillus boronitolerans have been reported to tolerate more than 450, 450, 300 and $150 \mathrm{mM}$ boron, respectively (Ahmed et al., 2007a, b, c, d), whereas Variovorax boronicumulans shows intracellular accumulation of boron (Miwa et al., 2008).

The genus Lysinibacillus was proposed recently following a re-examination of rRNA group 2 of the genus Bacillus (Ahmed et al., 2007d). Strains of the genus Lysinibacillus contain lysine and aspartate in the peptide subunit of the cell-wall peptidoglycan as diagnostic amino acids rather than meso-diaminopimelic acid, which is characteristic of the genus Bacillus. The type species of the genus is Lysinibacillus boronitolerans, and its other members are Lysinibacillus fusiformis and Lysinibacillus sphaericus.

In the course of exploring boron-accumulating bacteria, strain BAM- $582^{\mathrm{T}}$ was isolated from soil of the Hisarcik area in Kutahya province, Turkey. This area has been reported to contain significant amounts of boron minerals naturally 
(Çöl \& Çöl, 2003). In this article, we report the taxonomic properties of strain BAM-582 ${ }^{\mathrm{T}}$ isolated from naturally boron-containing soil, which clusters with members of the genus Lysinibacillus.

Strain BAM $-582^{\mathrm{T}}$ was isolated from a homogenized soil sample diluted with sterilized PBS ( $\mathrm{pH} 7.2$ ) on tryptic soya agar (TSA; Difco) and incubated at $25{ }^{\circ} \mathrm{C}$. Individual colonies isolated on TSA were used for the measurement of intracellular boron.

During preliminary screening for boron-accumulating isolates, intracellular boron was estimated by growing the isolates at $25{ }^{\circ} \mathrm{C}$ for 7 days in tryptic soya broth (TSB; Difco) containing $100 \mu \mathrm{M}$ boric acid (Wako); cells were harvested by centrifugation and analysed for intracellular boric acid by the azomethine-H method (Gupta \& Stewart, 1975). To determine the boron concentration more precisely, isolates were grown at $25{ }^{\circ} \mathrm{C}$ for 2 days in TSB (5 ml) containing $100 \mu \mathrm{M}$ boric acid, harvested, washed with TSB and analysed for boron content by inductively coupled plasma-mass spectrometry (ICP-MS; Seiko Instruments Industry). The weight of the freeze-dried pellet was used to calculate the intracellular boron concentration. Strain BAM-582 $2^{\mathrm{T}}$ contained a smaller amount of boric acid compared with closely related members of the genus Lysinibacillus (Supplementary Table S1, available in IJSEM Online) and thus was subjected to further characterization.

The temperature for optimum growth of the strain was determined by incubation at various temperatures from 4 to $45{ }^{\circ} \mathrm{C}$ for 2 weeks on TSA medium ( $\mathrm{pH}$ 7.2). The $\mathrm{pH}$ range for growth was determined using TSA adjusted to various $\mathrm{pH}$ values $(\mathrm{pH} 5.0-10.0$ at intervals of $1.0 \mathrm{pH}$ unit). The medium was buffered with $100 \mathrm{mM}$ MES for pH 5.0, $100 \mathrm{mM} \mathrm{NaH} \mathrm{PO}_{4}$ for $\mathrm{pH} 6.0-8.0$ and $100 \mathrm{mM}$ $\mathrm{Na}_{2} \mathrm{CO}_{3}$ for $\mathrm{pH} 9.0$ and 10.0 (Yumoto et al., 2004). The $\mathrm{pH}$ was adjusted using $\mathrm{KOH}$ or $\mathrm{HCl}$ prior to sterilization. $\mathrm{NaCl}$ tolerance was examined using TSA plates containing 0$10 \% \mathrm{NaCl}$. Boron tolerance was determined on TSA plates containing 25, 50, 100 and $150 \mathrm{mM}$ boric acid.

The motility and morphology of cells were observed using phase-contrast microscopy, and spore formation was examined as described previously (Ahmed et al., 2007a). Gram staining was performed according to Hucker's modified method (Cowan, 1974). Growth under anaerobic conditions was determined after 2 weeks incubation in an AnaeroPack (Mitsubishi Gas). Catalase and oxidase activities were determined as described by Yoon et al. (2006). API 20E and API ZYM galleries (bioMérieux) were used to examine physiological and biochemical characteristics; API 20E and API ZYM results were read after $48 \mathrm{~h}$ incubation at $25{ }^{\circ} \mathrm{C}$ and $4 \mathrm{~h}$ incubation at $37^{\circ} \mathrm{C}$, respectively. Utilization of various carbon sources was determined using API 50 strips (bioMérieux) and the Biolog GP2 MicroPlates (Biolog). The inoculated Biolog GP2 plate was incubated at $28{ }^{\circ} \mathrm{C}$ for $72 \mathrm{~h}$ before the results were read. Resistance to antibiotics was assessed by an ATB-VET strip (bioMérieux). All commercial kits were used according to the manufacturers' protocols unless otherwise mentioned. The results from API 20E, API$50 \mathrm{CH}$, Biolog GP2 and ATB-VET were compared with closely related species in Table 1 and additional characteristics are included in the species description.

The nearly complete 16S rRNA gene sequence of the strain was amplified by PCR as described by Katsivela et al. (1999). The purified PCR product was sequenced as described previously (Ahmed et al., 2007a). The 16S rRNA gene sequence of strain BAM- $582^{\mathrm{T}}$ was compared with sequences of closely related species with validly published names retrieved from GenBank. Alignment was performed with CLUSTAL_X software (Thompson et al., 1997). Gaps and ambiguous bases were not taken into consideration during comparison. Evolutionary distances and $K_{\text {nuc }}$ values (Kimura, 1980) were calculated. A phylogenetic tree was constructed using the neighbourjoining method and maximum-parsimony method using MEGA version 3.1 (Kumar et al., 2004) from alignment of 1283 bases of the $16 \mathrm{~S}$ rRNA gene. The stability of relationships was assessed by bootstrap analysis by performing 1000 resamplings for the tree topology.

The 16S rRNA gene sequence (1477 nt) of strain BAM$582^{\mathrm{T}}$ showed the highest similarity to the sequences of $L$. fusiformis NRRL NRS- $350^{\mathrm{T}}$ (98.2\%), L. sphaericus NRRL B-23268 ${ }^{\mathrm{T}}(97.7 \%)$, L. boronitolerans $10 \mathrm{a}^{\mathrm{T}}(96.6 \%)$, Bacillus massiliensis $4400831^{\mathrm{T}}(96.4 \%)$, Bacillus odysseyi $34 \mathrm{hs}-1^{\mathrm{T}}$ $(96.2 \%)$ and Bacillus silvestris HR3-23 ${ }^{\mathrm{T}}(95.6 \%)$, and lower sequence similarity (less than $96 \%$ ) to other neighbouring species. The phylogenetic tree constructed by the neighbour-joining method revealed that strain BAM- $582^{\mathrm{T}}$ clustered with the members of the genus Lysinibacillus at a high bootstrap value of $96 \%$ (Fig. 1), showing greater reliability of the phylogeny. Phylogenetic analysis by the maximum-parsimony algorithm produced a similar result (not shown).

Genomic DNA of the novel strain was prepared according to the standard protocol and DNA G $+\mathrm{C}$ content was determined by the HPLC method of Mesbah et al. (1989). DNA-DNA hybridizations of the novel strain with type strains of closely related species showing $16 \mathrm{~S}$ rRNA gene sequence similarity of more than $97 \%$ (Stackebrandt \& Goebel, 1994) were performed at $42{ }^{\circ} \mathrm{C}$ using a photobiotin-labelled DNA probe as described by Ezaki et al. (1989). DNA-DNA hybridization values between strain BAM-582 ${ }^{\mathrm{T}}$ and L. sphaericus IAM $13420^{\mathrm{T}}$ and L. fusiformis DSM $2898^{\mathrm{T}}$ were 29.5 and $33.9 \%$, respectively, indicating that strain BAM $-582^{\mathrm{T}}$ represents a separate species of the genus Lysinibacillus (Stackebrandt \& Goebel, 1994).

For whole-cell fatty acid analysis, cells were grown on TSA for $24 \mathrm{~h}$ at $28{ }^{\circ} \mathrm{C}$ and the cellular fatty acid profile was determined using the GC-based Microbial Identification system (MIDI; version 4.0) according to the manufacturer's instructions. Analysis of the respiratory quinone system was performed as described by Xie \& Yokota 
Table 1. Characteristics that differentiate strain BAM $-582^{\top}$ from species of the genus Lysinibacillus

Strains/species: 1, strain BAM-582 $;$, L. boronitolerans $10 \mathrm{a}^{\mathrm{T}}$ (unless indicated, data from Ahmed et al., 2007d); 3, L. fusiformis (Priest et al., 1988); 4, L. sphaericus (Claus \& Berkeley, 1986). All members of the genus produced positive results for motility, growth without $\mathrm{NaCl}$ and catalase and negative results for $\mathrm{H}_{2} \mathrm{~S}$ production, nitrate reduction, oxidation of $\beta$-hydroxybutyrate and indole production. + , Positive or $>85 \%$ of strains positive; $+\mathrm{w}$, weakly positive; -, negative; $\mathrm{v}$, variable; ND, no data available.

\begin{tabular}{|c|c|c|c|c|}
\hline Characteristic & 1 & 2 & 3 & 4 \\
\hline Cell length $(\mu \mathrm{m})$ & $2.0-5.0$ & $3.0-5.0$ & ND & $1.5-5.0$ \\
\hline Cell diameter $(\mu \mathrm{m})$ & $0.5-1.0$ & $0.8-1.5$ & ND & $0.6-1.0$ \\
\hline Spore shape and position ${ }^{\star}$ & $\mathrm{R}, \mathrm{T}, \mathrm{B}$ & $\mathrm{R} / \mathrm{O}, \mathrm{T}, \mathrm{B}$ & $\mathrm{R}, \mathrm{C} / \mathrm{T}, \mathrm{B}$ & $\mathrm{R}, \mathrm{T}, \mathrm{B}$ \\
\hline Temperature range for growth $\left({ }^{\circ} \mathrm{C}\right)$ & $10-37$ & $16-45$ & $17-40$ & $10-40$ \\
\hline $\mathrm{pH}$ range for growth & $6-8$ & $5.5-9.5$ & $6.0-9.5$ & $6.0-9.5$ \\
\hline \multicolumn{5}{|l|}{ Growth in: } \\
\hline $\mathrm{NaCl}(7 \%, \mathrm{w} / \mathrm{v})$ & - & - & + & - \\
\hline Boron $(\mathrm{mM})$ & 50 & 150 & $60^{a_{\dagger}}$ & $75^{a}$ \\
\hline Voges-Proskauer test & + & + & - & - \\
\hline Oxidase & - & + & + & + \\
\hline L-Arginine dihydrolase & - & + & ND & ND \\
\hline Tryptophan deaminase & $+\mathrm{w}$ & + & ND & - \\
\hline \multicolumn{5}{|l|}{ Hydrolysis of: } \\
\hline Urea & + & + & + & - \\
\hline Gelatin & - & - & + & + \\
\hline Aesculin & $+\mathrm{w}$ & $+\mathrm{w}$ & - & - \\
\hline \multicolumn{5}{|l|}{ Acid production from: } \\
\hline Sucrose & - & - & $\mathrm{v}$ & - \\
\hline D-Xylose & - & $+\mathrm{w}$ & - & - \\
\hline $\mathrm{N}$-Acetyl-D-glucosamine & - & + & ND & ND \\
\hline \multicolumn{5}{|l|}{ Resistance to $\left(\mu \mathrm{g} \mathrm{ml}^{-1}\right)$ : } \\
\hline Chloramphenicol (8) & + & - & + & $+w$ \\
\hline Erythromycin (1) & - & - & + & $+\mathrm{w}$ \\
\hline Rifampicin (0.25) & - & - & - & $+\mathrm{w}$ \\
\hline Streptomycin (8) & + & - & $+\mathrm{w}$ & + \\
\hline Tetracycline (2) & - & - & - & + \\
\hline \multicolumn{5}{|l|}{ Oxidation of: } \\
\hline Pyruvate & - & + & $+^{b}$ & $++^{b}$ \\
\hline$\alpha$-Hydroxybutyrate & - & + & $-{ }^{b}$ & $-{ }^{b}$ \\
\hline L-Alanine & - & + & $+{ }^{b}$ & $++^{b}$ \\
\hline Glycyl L-glutamate & - & + & $+{ }^{b}$ & $+{ }^{b}$ \\
\hline Adenosine & - & + & $+{ }^{b}$ & $++^{b}$ \\
\hline $2^{\prime}$-Deoxyadenosine & - & + & $+{ }^{b}$ & $++^{b}$ \\
\hline Inosine & - & + & $+{ }^{b}$ & $++^{b}$ \\
\hline AMP & - & + & $++^{b}$ & $+{ }^{b}$ \\
\hline UMP & - & + & $++^{b}$ & $++^{b}$ \\
\hline Presence of iso- $\mathrm{C}_{16: 1}$ & + & - & - & - \\
\hline
\end{tabular}

${ }^{\star} \mathrm{B}$, Bulging; $\mathrm{C}$, central; $\mathrm{O}$, oval or slightly oval; $\mathrm{R}$, round; $\mathrm{T}$, terminal. $\dagger$ Data for the type strains taken from: a, Ahmed et al. (2007d); b, La Duc et al. (2004).

(2003). The purified cell wall was analysed for amino acids using two-dimensional TLC and HPLC (Shimadzu) as described elsewhere (Schleifer \& Kandler, 1972; Groth et al., 1996). Polar lipids were extracted and purified from $100 \mathrm{mg}$ dried cells by the procedure of Minnikin et al. (1984) and examined by two-dimensional TLC, using Kieselgel $60 \mathrm{~F}_{254}$ plates (Merck), as described by Kudo (2001).
Major cellular fatty acids of strain BAM-582 ${ }^{\mathrm{T}}$ were iso$\mathrm{C}_{15: 0}(37.4 \%)$, anteiso- $\mathrm{C}_{15: 0}(19.0 \%)$ and anteiso- $\mathrm{C}_{17: 0}$ $(9.6 \%)$. This result is similar to those obtained from other members of the genus Lysinibacillus (Table 2); however, the presence of iso- $\mathrm{C}_{16: 1}(4.9 \%)$ distinguished the strain from other members of the genus Lysinibacillus. The major quinone system of strain BAM-582 ${ }^{\mathrm{T}}$ was menaquinone MK-7. Cell-wall analysis for diagnostic amino acids 


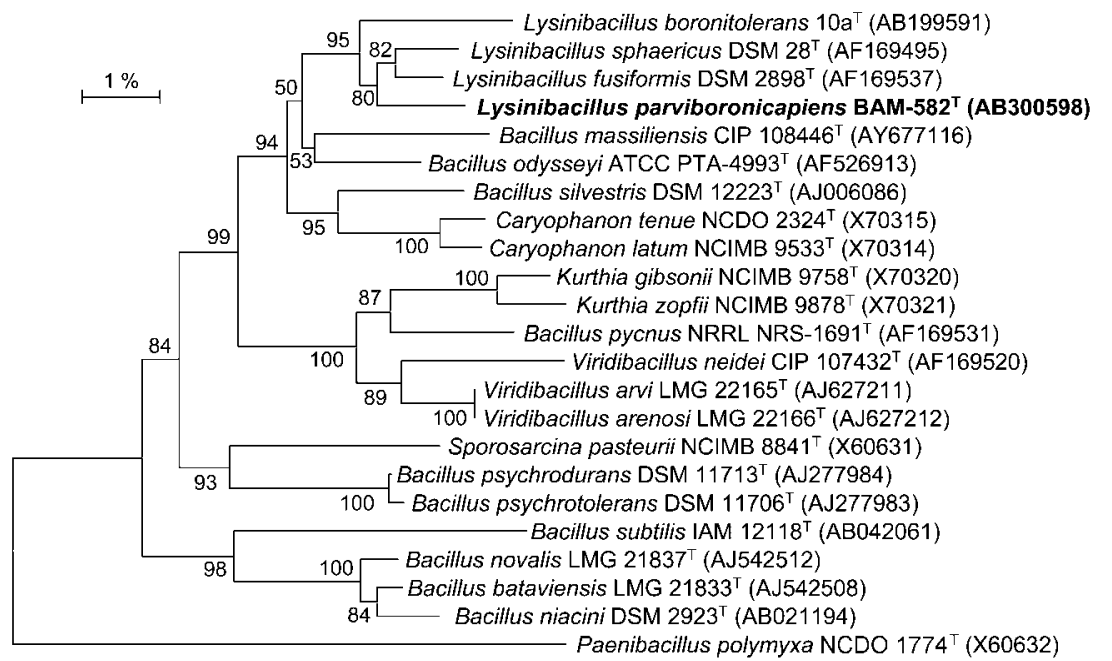

Fig. 1. Neighbour-joining phylogenetic tree of the members of the genus Lysinibacillus and representatives of some other taxa based on 16S rRNA gene sequence comparisons. Bootstrap values of $50 \%$ or above (from 1000 replicates) are shown at nodes. The sequence of Paenibacillus polymyxa NCDO $1774^{\top}$ was used as the outgroup. Bar, $1 \%$ sequence divergence. revealed that strain BAM-582 $2^{\mathrm{T}}$ contained peptidoglycan with alanine, glutamic acid, lysine and aspartic acid in a molar ratio of $1.93: 1.0: 0.86: 0.89$. This composition is similar to those obtained for L. boronitolerans, L. fusiformis and L. sphaericus (Ahmed et al., 2007d) and represents peptidoglycan type A4 $\alpha$ (Lys-Asp), as described by Schleifer \& Kandler (1972). Strain BAM-582 ${ }^{\mathrm{T}}$ shared a similar polar lipid profile with other species of the genus Lysinibacillus, consisting predominantly of diphosphatidylglycerol, phosphatidylglycerol and a ninhydrin-positive phosphoglycolipid (Supplementary Fig. S1). The ninhydrin-positive phosphoglycolipid found in strain BAM-582

Table 2. Cellular fatty acid compositions (\%) of strain BAM$582^{\top}$ and type strains of other species of the genus Lysinibacillus

Strains: 1 , BAM- $582^{\mathrm{T}} ; 2$, L. boronitolerans $10 \mathrm{a}^{\mathrm{T}} ; 3$, L. fusiformis DSM $2898^{\mathrm{T}}$; 4, L. sphaericus IAM $13420^{\mathrm{T}}$. Data for reference strains were taken from Ahmed et al. (2007d).

\begin{tabular}{|c|c|c|c|c|}
\hline Fatty acid & 1 & 2 & 3 & 4 \\
\hline $\mathrm{C}_{14: 0}$ & 0.9 & 0.4 & 1.0 & 0.4 \\
\hline $\mathrm{C}_{15: 0}$ & 0.4 & 0.5 & 1.1 & - \\
\hline $\mathrm{C}_{16: 0}$ & 4.1 & 1.8 & 3.5 & 0.7 \\
\hline iso- $\mathrm{C}_{14: 0}$ & 5.9 & 1.7 & 2.8 & 2.3 \\
\hline iso- $\mathrm{C}_{15: 0}$ & 37.4 & 31.8 & 23.9 & 41.9 \\
\hline anteiso- $\mathrm{C}_{15: 0}$ & 19 & 21.4 & 17.9 & 4.7 \\
\hline iso- $\mathrm{C}_{16: 0}$ & 5.9 & 11.2 & 15.7 & 8.2 \\
\hline iso- $\mathrm{C}_{16: 1}$ & 4.9 & - & - & - \\
\hline iso- $\mathrm{C}_{17: 0}$ & 7.9 & 5.5 & 4.4 & 7.0 \\
\hline anteiso- $\mathrm{C}_{17: 0}$ & 9.6 & 11.1 & 9.2 & 1.7 \\
\hline iso- $\mathrm{C}_{17: 1} \omega 10 c$ & 0.9 & 1.3 & 0.9 & 8.3 \\
\hline $\mathrm{C}_{16: 1} \omega 7 c$ alcohol & 4.2 & 7.6 & 11.6 & 18.3 \\
\hline $\mathrm{C}_{16: 1} \omega 11 c$ & 4.9 & 2.7 & 5.8 & 3.3 \\
\hline Summed feature $4^{*}$ & 2.7 & 2.8 & 2.2 & 2.2 \\
\hline
\end{tabular}

${ }^{*}$ Summed feature 4 comprises iso- $\mathrm{C}_{17: 1} \mathrm{I}$ and/or anteiso- $\mathrm{C}_{17: 1} \mathrm{~B}$. shows identical chromatographic behaviour to one reported in L. sphaericus, suggesting that strain BAM$582^{\mathrm{T}}$ is closely related to L. sphaericus. An unknown polar lipid (L1) detected in strain BAM- $582^{\mathrm{T}}$ is absent from the polar lipid profiles of L. boronitolerans and L. fusiformis, whereas phosphatidylethanolamine is absent from the polar lipid profile of $L$. sphaericus. These chemotaxonomic analyses further confirmed that strain BAM- $582^{\mathrm{T}}$ belongs to the genus Lysinibacillus.

The phylogenetic and genotypic analyses, chemotaxonomic distinctiveness and differential phenotypic properties were sufficient to categorize strain BAM-582 ${ }^{\mathrm{T}}$ as a member of the genus Lysinibacillus, and to differentiate BAM-582 ${ }^{\mathrm{T}}$ from other related species. Therefore, strain BAM- $582^{\mathrm{T}}$ is classified as the type strain of a novel species of the genus Lysinibacillus, for which the name Lysinibacillus parviboronicapiens sp. nov. is proposed.

\section{Description of Lysinibacillus parviboronicapiens sp. nov.}

Lysinibacillus parviboronicapiens (par'vi.bo' ro.ni.ca' pi.ens. L. adj. parvus little, low; N.L. n. boron boron; L. part. adj. capiens containing; N.L. part. adj. parviboronicapiens containing little boron).

Cells are Gram-positive-staining rods $(0.5-1.0 \times 2.0-$ $5.0 \mu \mathrm{m})$. Colonies on TSA are circular with entire margins, opaque and creamy and $2-5 \mathrm{~mm}$ in diameter after 3 days incubation at $30{ }^{\circ} \mathrm{C}$. Temperature range for growth is $10-$ $37{ }^{\circ} \mathrm{C}$ with optimum growth at $30{ }^{\circ} \mathrm{C}$. Growth is observed in the range $\mathrm{pH} 6-8$, with optimum growth at $\mathrm{pH} 7$; no growth at $\mathrm{pH}$. Tolerates $0-50 \mathrm{mM}$ boron but grows optimally without boron supply. $\mathrm{NaCl}$ tolerance range is 0 $6 \%(\mathrm{w} / \mathrm{v})$ in TSA, indicating that it is moderately halotolerant. Anaerobic growth does not occur on TSA. Catalase activity is positive, whereas oxidase reaction is negative. Positive for Voges-Proskauer and urease tests and weakly positive for tryptophan deaminase, but negative for 
ONPG, citrate utilization, arginine dihydrolase, lysine and ornithine decarboxylases and production of hydrogen sulfide and indole. Acid is produced from aesculin ferric citrate, $\mathrm{N}$-acetylglucosamine, lactose and 5-ketogluconate, but not from the other substrates of the Biolog GP2 plate. Positive for esterase lipase (C8) and chymotrypsin, but negative for alkaline phosphatase, leucine arylamidase, valine arylamidase, trypsin, acid phosphatase, naphtholAS-BI-phosphohydrolase, esterase (C4), lipase (C4), cystine arylamidase, $\alpha$-galactosidase, $\beta$-galactosidase, $\beta$ glucuronidase, $\alpha$-glucosidase, $\beta$-glucosidase, $N$-acetyl- $\beta$ glucosaminidase, $\alpha$-mannosidase and $\alpha$-fucosidase. Resistant to lincomycin, colistin, enrofloxacin, metronidazole, fusidic acid, flumequine, oxolinic acid, streptomycin and chloramphenicol (ATB-VET strip). The $\mathrm{G}+\mathrm{C}$ content of the type strain is $38.7 \mathrm{~mol} \%$.

Strain BAM $-582^{\mathrm{T}}\left(=\mathrm{NBRC} 103144^{\mathrm{T}}=\mathrm{KCTC} 13154^{\mathrm{T}}\right)$ is the type strain, isolated from soil collected in the Hisarcik area of Turkey.

\section{Acknowledgements}

We thank Mr Jaewoo Yoon for technical guidance and suggestions and $\mathrm{Mr} \mathrm{V}$. V. Bautista for help with the menaquinone analysis. We are indebted to Dr J. P. Euzéby (Ecole Nationale Vétérinaire, Toulouse, France) for the etymology of the new name.

\section{References}

Ahmed, I., Yokota, A. \& Fujiwara, T. (2007a). A novel highly borontolerant bacterium, Bacillus boroniphilus sp. nov., isolated from soil, that requires boron for its growth. Extremophiles 11, 217-224.

Ahmed, I., Yokota, A. \& Fujiwara, T. (2007b). Gracilibacillus boraciitolerans sp. nov., a highly boron-tolerant and moderately halotolerant bacterium isolated from soil. Int J Syst Evol Microbiol 57, 796-802.

Ahmed, I., Yokota, A. \& Fujiwara, T. (2007c). Chimaereicella boritolerans sp. nov., a boron-tolerant and alkaliphilic bacterium of the family Flavobacteriaceae isolated from soil. Int J Syst Evol Microbiol 57, 986-992.

Ahmed, I., Yokota, A., Yamazoe, A. \& Fujiwara, T. (2007d). Proposal of Lysinibacillus boronitolerans gen. nov., sp. nov., and transfer of Bacillus fusiformis to Lysinibacillus fusiformis comb. nov. and Bacillus sphaericus to Lysinibacillus sphaericus comb. nov. Int J Syst Evol Microbiol 57, 1117-1125.

Bolaños, L., Redondo-Nieto, M., Bonilla, I. \& Wall, L. G. (2002). Boron requirement in the Discaria trinervis (Rhamnaceae) and Frankia symbiotic relationship. Its essentiality for Frankia BCU110501 growth and nitrogen fixation. Physiol Plant 115, 563-570.

Bonilla, I., García-González, M. \& Mateo, P. (1990). Boron requirement in cyanobacteria. Its possible role in the early evolution of photosynthetic organisms. Plant Physiol 94, 1554-1560.

Chen, X., Schauder, S., Potier, N., Dorsselaer, A. V., Pelczer, I., Bassler, B. L. \& Hughson, F. M. (2002). Structural identification of a bacterial quorum-sensing signal containing boron. Nature 415, 545-549.

Claus, D. \& Berkeley, R. C. W. (1986). Genus Bacillus Cohn 1872, $174^{\mathrm{AL}}$. In Bergey's Manual of Systematic Bacteriology, vol. 2, pp. 11051139. Edited by P. H. A. Sneath, N. S. Mair, M. E. Sharpe \& J. G. Holt. Baltimore: Williams \& Wilkins.
Çöl, M. \& Çöl, C. (2003). Environmental boron contamination in waters of the Hisarcik area in the Kutahya Province of Turkey. Food Chem Toxicol 41, 1417-1420.

Cowan, S. T. (1974). Cowan and Steel's Manual for the Identification of Medical Bacteria, 2nd edn. London: Cambridge University Press.

Ezaki, T., Hashimoto, Y. \& Yabuuchi, E. (1989). Fluorometric deoxyribonucleic acid-deoxyribonucleic acid hybridization in microdilution wells as an alternative to membrane filter hybridization in which radioisotopes are used to determine genetic relatedness among bacterial strains. Int J Syst Bacteriol 39, 224-229.

Groth, I., Schumann, P., Weiss, N., Martin, K. \& Rainey, F. A. (1996). Agrococcus jenensis gen. nov., sp. nov., a new genus of actinomycetes with diaminobutyric acid in the cell wall. Int J Syst Bacteriol 46, 234239.

Gupta, S. K. \& Stewart, J. W. B. (1975). The extraction and determination of plant-available boron in soils. Schweiz Landwirtsch Forsch 14, 153-169.

Katsivela, E., Bonse, D., Krüger, A., Strömpl, C., Livingston, A. \& Ittich, R.-M. (1999). An extractive membrane biofilm reactor for degradation of 1,3-dichloropropene in industrial wastewater. Appl Microbiol Biotechnol 52, 853-862.

Kimura, M. (1980). A simple method for estimating evolutionary rates of base substitutions through comparative studies of nucleotide sequences. J Mol Evol 16, 111-120.

Kudo, T. (2001). Phospholipids. In Identification Manual of Bacteria: Molecular Genetics and Molecular Biological Methods, Springer Lab Manual, pp. 135-144. Edited by K. Suzuki, A. Hiraishi \& A. Yokota. Tokyo: Springer. ISBN: 4-431-70930-4 C3045 (in Japanese).

Kumar, S., Tamura, K. \& Nei, M. (2004). MEGA3: integrated software for molecular evolutionary genetics analysis and sequence alignment. Brief Bioinform 5, 150-163.

La Duc, M. T., Satomi, M. \& Venkateswaran, K. (2004). Bacillus odysseyi sp. nov., a round-spore-forming bacillus isolated from the Mars Odyssey spacecraft. Int J Syst Evol Microbiol 54, 195-201.

Loomis, W. D. \& Durst, R. W. (1992). Chemistry and biology of boron. Biofactors 3, 229-239.

Mesbah, M., Premachandran, U. \& Whitman, W. B. (1989). Precise measurement of the $\mathrm{G}+\mathrm{C}$ content of deoxyribonucleic acid by highperformance liquid chromatography. Int J Syst Bacteriol 39, 159-167.

Minnikin, D. E., O'Donnell, A. G., Goodfellow, M., Alderson, G., Athalye, M., Schaal, A. \& Parlett, J. H. (1984). An integrated procedure for the extraction of bacterial isoprenoid quinones and polar lipids. J Microbiol Methods 2, 233-241.

Miwa, H., Ahmed, I., Yoon, J., Yokota, A. \& Fujiwara, T. (2008). Variovorax boronicumulans sp. nov., a boron-accumulating bacterium isolated from soil. Int J Syst Evol Microbiol 58, 286-289.

Nielsen, F. H. (2004). Boron. In Elements and their Compounds in the Environment, 2nd edn, pp. 1251-1260. Edited by E. Merian, M. Anke, M. Ihnat \& M. Stoeppler. Weinheim: Wiley-VCH.

Otero, L., Palacio, V., Mendez, F. J. \& Vazquez, F. (2002). Boric acid susceptibility testing of non-C. albicans Candida and Saccharomyces cerevisiae: comparison of three methods. Med Mycol 40, 319-322.

Priest, F. G., Goodfellow, M. \& Todd, C. (1988). A numerical classification of the genus Bacillus. J Gen Microbiol 134, 1847-1882.

Rowe, R. I. \& Eckhert, C. D. (1999). Boron is required for zebrafish embryogenesis. J Exp Biol 202, 1649-1654.

Rowe, R. I., Bouzan, C., Nabili, S. \& Eckhert, C. D. (1998). The response of trout and zebrafish embryos to low and high boron concentrations is U-shaped. Biol Trace Elem Res 66, 261-270.

Schleifer, K. H. \& Kandler, O. (1972). Peptidoglycan types of bacterial cell walls and their taxonomic implications. Bacteriol Rev 36, 407-477. 
Stackebrandt, E. \& Goebel, B. M. (1994). Taxonomic note: a place for DNA-DNA reassociation and $16 \mathrm{~S}$ rRNA sequence analysis in the present species definition in bacteriology. Int J Syst Bacteriol 44, 846-849.

Swate, T. E. \& Weed, J. C. (1974). Boric acid treatment of vulvovaginal candidiasis. Obstet Gynecol 43, 893-895.

Thompson, J. D., Gibson, T. J., Plewniak, F., Jeanmougin, F. \& Higgins, D. G. (1997). The CLUSTAL_X windows interface: flexible strategies for multiple sequence alignment aided by quality analysis tools. Nucleic Acids Res 25, 4876-4882.

Warington, K. (1923). The effect of boric acid and borax on the broad bean and certain other plants. Ann Bot (Lond) 37, 629-672.
Xie, C. H. \& Yokota, A. (2003). Phylogenetic analysis of Lampropedia hyalina based on the 16S rRNA gene sequence. J Gen Appl Microbiol 49, 345-349.

Yoon, J., Maneerat, S., Kawai, F. \& Yokota, A. (2006). Myroides pelagicus sp. nov., isolated from seawater in Thailand. Int J Syst Evol Microbiol 56, 1917-1920.

Yumoto, I., Hirota, K., Yamaga, S., Nodasaka, Y., Kawasaki, T., Matsuyama, H. \& Nakajima, K. (2004). Bacillus asahii sp. nov., a novel bacterium isolated from soil with the ability to deodorize the bad smell generated from short-chain fatty acids. Int J Syst Evol Microbiol 54, 1997-2001. 